KOPHÁZI-MOLNÁR Erzsébet

Szent István Egyetem Pedagógiai Kar

ORCID: 0000-0002-6526-1469

Kophazi-Molnar.Erzsebet@szie.hu

\section{Mesék befogadásának mérése - egy lehetséges modell}

Gyerekek körében felmérést végezni mindig nagy kihívás. Ha nagy mintát szeretnénk felmérni, az különösen időigényes feladat lehet. Ha kérdőívet szeretnénk kitöltetni velük, nem biztos, hogy azt az információt kapjuk, amire igazán vágyunk. Ha a mesélés során szerzett élményeiket szeretnénk megragadni a hallott mesével kapcsolatban, ez igazán nehéz eröpróba jelent. Könnyú abba a hibába esni, hogy az általunk fontosnak vélt információra vagyunk kíváncsiak a történet megértésével kapcsolatban, s erről inkább kikérdezni szeretnénk őket, aztán végül nem a saját élményeik jönnek elö.

A jelen kutatás célja az volt, hogy bemutasson egy lehetséges modellt, melynek segítségével kicsi gyerekek körében is viszonylag egyszerüen végezhetünk felmérést a mesehallgatás során szerzett élményekről. A szabad szóasszociáció módszerével azt vizsgáltuk, hogy a gyerekek hogy viszonyulnak különböző meseátirat-típusokhoz, illetve az eredeti történetekhez.

A fö kutatást megelőzően egy elővizsgálatot végeztünk, melynek során közel négyszáz, föként második osztályos diák szavakat és kifejezéseket írt le azzal kapcsolatban, mitől tetszenek nekik a mesék. Az itemek listázása után kódolókat kértünk fel, hogy a megjegyzéseket rendezzék különböző kategóriákba - ezek adták aztán a későbbi összehasonlítások alapját. Hat olyan mesepárt választottunk (egy klasszikus történetet és annak modern párját), melyek közül a modern verzió az átiratfajták egy-egy típusát képviselte. Egy elötesztelést követően a mesepárokat elmeséltük hat különböző iskolában harminc második osztályos tanulónak (tizenöt fiúnak és tizenöt lánynak). A szabad szóasszociáció mellett használtunk egy hat hőmérốt ábrázoló lapot, melyek a kéktől a piros színig terjedő színárnyalatokkal fejeztek ki egy-egy értéket, egy tulajdonképpen hatfokozatú skálán. Ezen a megkérdezetteknek meg kellett jelölniük a tetszés fokát, majd a lap hátoldalán le kellett írniuk azokat a kifejezéseket vagy szavakat, hogy mitôl tetszett nekik az adott mese. A lapokat kóddal láttuk el, és a hömérôn található értékeket SPSS-programmal kiértékeltük. Ezek az értékek azonban nem minden esetben estek egybe azzal, amit (és amennyit!) a gyerekek a tetszésrôl írtak. Így a kapott értékek és az írásbeli válaszok egybevetése igazán izgalmas feladatot jelentett.

Kulcsszavak: modern meseátirat-típusok, morfológiai vizsgálat, mesék befogadása, szabad szóasszociáció

A művészeti alkotások - s benne az irodalmi művek, jelen esetben a mesék - esztétikai értékeket testesítenek meg, melyek a befogadóból, a befogadóban különböző érzéseket, élményeket váltanak ki. A kutatók ennek megfelelően több területen is foglalkoznak ezzel a kérdéssel, így a szociológia, a pszichológia és az esztétika nézőpontjából is. Létezik 
azonban kifejezetten művészetpszichológia is, mely Halász László megfogalmazásában „[...] az esztétika és a pszichológia határtudománya. [...] A művészetpszichológia jelentősen támaszkodik az észlelésről, emlékezésről, képzeletről, a gondolkodásról és az érzelmekről feltárt általános pszichológiai ismeretanyagra, szemléletre, vizsgálati eljárásra" (Halász 2006: 187). A műbefogadás kapcsán tehát nagyon sok fogalommal és az alkotó folyamat különböző szereplőivel és fázisaival találjuk magunkat szembe. Természetesen egy-egy kutató jellemzően egy-egy nézőpontból vizsgálódik. Vannak, akik inkább elméleti, mások történeti, illetve módszertani, esetleg pedagógiai szempontból közelítik meg a befogadás aktusát.

Abban azonban a kutatók nagy része egyetért, hogy a művészetpszichológiai kutatások főbb területei a művész, maga az alkotás folyamata, az alkotás, a befogadó és a befogadás. Ennek megfelelően Halász László szerint „[...] míg a tradicionális művészettudományok a művekre - létformájukra, történeti összefüggéseikre, értékelésükre - helyezik a hangsúlyt, a művészetpszichológia a viselkedés, az élmény, a belső feltételek tanulmányozására. Azaz a művészi teljesítmény létrehozását és felfogását befolyásoló pszichológiai mechanizmusok feltárására törekszik" (Halász 2006: 188). Szempontunkból a fogalmak közül a befogadás folyamata a fontos, mely Halász szerint egy izgalommal járó állapot. A mű élvezete annak függvénye, mennyi jelentéstartalmat talál a befogadó az adott műben. Halász megkülönbözteti az empátia és az azonosulás fogalmát, melyek közül az első képzeleti folyamat is, de ennek nem szükségszerű következménye az azonosulás. Más helyzetben vagyunk, ha valóságos emberek helyébe képzeljük bele magunkat, melynek során azonban nem akarunk olyan lenni, mint a másik ember. A műalkotások képzeletbeli személyeit a befogadó reproduktív képzelete segítségével hozza létre, de a róluk szerzett információ valósként épülhet be az ismeretrendszerébe. Halász úgy véli, „[...] a befogadó és a hős között bármekkora legyen is a távolság (státustól a jellemvonásokig), mindig van annyi találkozási pont - az emberi megnyilatkozások hallatlanul széles regisztere és plaszticitása, illetve az ön- és társészlelés ingatagsága miatt -, amennyi lehetőséget ad az azonosulásra. Ennek során a befogadó (fellépő) feszültségeitől időlegesen megszabadulhat. Közel kerülünk a mű terápiai hatásához, a katarzishoz" (Halász 2006: 198). Ez utóbbi fogalmat ő úgy definiálja, mint olyat, melynek során indulati feszültségek oldódnak fel az alkotóban és a befogadóban egyaránt.

Gyöngyösiné Kiss Enikő Halászhoz hasonlóan a művész, a műalkotás és a befogadó triászából indul ki, ő azonban kifejezetten a szépirodalom és a pszichológia közös pontjait keresi, s számára is a múvészetpszichológiai kutatások harmadik területe a befogadó kérdése. Ha az irodalmi műelemzést a befogadó oldaláról vizsgáljuk, azt reader-response megközelítésnek nevezzük, melyet Gyöngyösiné röviden így foglal össze: „Elméleti kiindulópontja, hogy az olvasás maga ugyanolyan alkotói tevékenységet jelent, akár egy színdarab előadása vagy egy zenei mű megszólaltatása. Az irodalom ugyanis csak akkor létezik, ha elolvassák, az olvasás során történő jelentésadás pedig alkotótevékenységként fogható fel. A reader-response megközelítés egy másik fő feltétele, hogy az irodalmi szövegnek nincs egy előre rögzített, helyes vagy végső jelentése, ehelyett az irodalom voltaképp a mű és az olvasó közötti folyamatos dialógusként fogható fel" (Gyöngyösiné 2007: 191). Az ilyen típusú megközelítést nevezzük tranzaktív befogadásnak, tranzaktív irodalomtudományon pedig azt a szemléletet értjük, mely megköveteli az értelmező személyes részvételét a szövegben.

Tibori Tímea kutatásai hasonló megállapításokat tartalmaznak, mint a fent említett gondolatok. „Számos külső és belső tényező alakítja a befogadás milyenségét” (Tibori 1995: 119), írja tanulmányában, de azt is hozzáteszi, fontos megvizsgálnunk, hogyan válik a mennyiségi megismerés minőséggé. Fontos az egyén úgynevezett „innovációs 
készsége", mely előfeltétele annak, hogy valaki önálló, alkotó módon közelítsen meg egy művet. De más tényezők is szerepet játszanak ebben. „Befolyásolják saját és a társadalom részéről jelentkező igények, motivációk, az az attitűdsor, amely adekvátan változik bármely külső és belső mozgás esetében” (Tibori 1995: 120). Tibori a fentiek alapján a befogadás négy lépcsőjét különbözteti meg, melyeket „állapotoknak” nevez. Az első a „minéműségi állapot”. „Ezt tekinthetjük a befogadás elemi szintjének, ahol az érzékelést és észlelést követően a véleményalkotás egyben a személynek a környezethez füződő morális viszonyát is kifejezi” (Tibori 2013: 209). A második az úgynevezett „faktuális állapot”, melynek során „,[...] az elemi szintről elmozdulás történhet a feldolgozás, a szintetizálás felé” (Tibori 2013: 209). A harmadik a „mennyiségi állapot”, ahol „[...] az egyén nemcsak a műre, hanem annak társadalmi környezetére is reagál” [...] s végül a „minőségi állapot”, mely „[...] a befogadás kiteljesedését jelentheti, ha az egyén a művet komplex módon értelmezi, a jelentését kitágítja a teljes univerzumra" (Tibori 2013: 210).

László János a fentiektől újabb, Pszichológia, irodalom, elbeszélés (2002) című tanulmánya adalékul szolgál a korszak irodalompszichológiai vizsgálataihoz, és ismerteti azokat a modelleket, melyeket megtalálhatunk a vizsgálatok hátterében. Az egyik ilyen az irodalomolvasás élményfeldolgozási modellje. „A nyolcvanas évek elejére a hazai pszichológiában is meghatározóvá vált a kognitív pszichológiai paradigma. Jóllehet a kognitív lélektan, mint a mentális élet pszichológiája, elsősorban az információfeldolgozásra koncentrált, a kognitív reprezentációkra irányuló kutatás elvben lehetőséget teremtett a szűk értelemben felfogott információk vagy ismeretek feldolgozásán túl a kontextusfüggő, érzelemteli élmények és jelentések reprezentációs sajátosságainak vizsgálatára is" (László 2002: 325). Kísérletei során bebizonyosodott, hogy mindig vannak élményszerű momentumok a szövegfeldolgozásban, ha azt az irodalmi szöveget megértési szándékkal olvassák, vagyis egy szubjektivizált szövegfeldolgozás, melyben az olvasó személyesen viszonyul az olvasottakhoz. A második modell a szociális-kognitív, melynek célja az, hogy empirikus úton tárja fel az olvasási jelentésképzés folyamatait. Az irodalmi jelentéshez a szöveg és az olvasó szociokulturális ismereteinek találkozása szükségeltetik, s ezzel az eljárással azt lehet megvizsgálni, „,hogy az olvasók hogyan vezetik be általános világismereteiket, illetve konkrét személyes élményeiket egy irodalmi elbeszélés megértésébe" (László 2002: 326). A következő lépcsőfokot a narratív pszichológia és a narratív pszichológiai tartalomelemzés eljárása jelenti, mely „[...] egyik lényeges újítása, hogy a pszichológiai tartalommal azonosított szövegelemet a pszichológia változó megjelenéseként értelmezi, és a gyakoriság alapján azonmód kvantifikálja azt. A másik lényeges újítás az elbeszéléses szerveződés és a pszichikus szerveződés közötti korreszpondenciák felismeréséből adódik, vagyis abból, hogy az én-elbeszélések narratív tulajdonságai, például a szereplők funkciói, az időviszonyok vagy a történetben használt perspektívák az én-reprezentációk tulajdonságairól és állapotairól, a világról szóló elbeszélések pedig a szociális reprezentációk pszichológiai tulajdonságairól adnak információt" (László 2002: 329-330).

Józsa Péter kutatásai némiképp hasonlítanak a fent idézettekre, mivel ő az esztétikai alkotás hatásmechanizmusának társadalmi jellegére helyezi a hangsúlyt. „Az esztétikai befogadás folyamata, úgy ahogyan az egyénben konkrétan lejátszódik, nyilvánvalóan pszichológiai folyamat. [...] mindazonáltal társadalmi természetű folyamat, nevezetesen abban az értelemben, hogy [...] olyan pszichológiai folyamat, amelyet legfontosabb etapjaiban társadalmi természetű tényezők determinálnak" (Józsa 1982: 355). Három tényezőt különít el vizsgálatai során: az esztétikai anyagot, a befogadót és az esztétikai hatásmechanizmust. Az első kategóriába tartozó esztétikai anyag kapcsán Józsa az irodalommal, a festészettel, a zenével és a filmmel foglalkozik két tengely, a narrativitás-nem- 
narrativitás, illetve a vizualitás-akuszticitás mentén. Van azonban a műveknek egy belső struktúrája is, amelyben különböző hatáselemek találhatóak, melyek működése „,...] kétdimenziós rendszerben rendezhető, ahol is az egyik tengely a szóban forgó kategóriáknak a művön belüli fajsúlya lesz, a másik pedig az olvasók/nézők kategóriánkénti viszonylagos érzékenysége. Vagyis a regények, a filmek, a képek különböznek egymástól aszerint, hogy struktúrájukban mekkora a szerepe a szóban forgó kategóriáknak; az olvasók/nézők pedig különböznek egymástól aszerint, hogy mennyire érzékenyek egyik vagy másik kategóriára" (Józsa 1982: 339-340). A Józsa által felállított második kategória a befogadó, akinek három olyan dimenzióját vizsgálja, amely hatással van magára a befogadási folyamatra. Az első az aktivitás-passzivitás, mely Józsa kísérleteiben a kapott válaszok alapján megfelel a tudatos-naiv ellentétpárnak. Ez a fogalompár azokat a különbségeket jelenti, mennyire képes a befogadó függetleníteni magát az elsődleges hatásoktól az élmények feldolgozása során. A második dimenziót az értelmezés dimenziójának nevezi, mely azt jelenti, hogy „[...] a szó szoros értelemben vett intellektuális aktivitással van dolgunk: a befogadónak azzal a hajlamával, szokásával vagy - mondjuk - akár kényszerével, hogy értelmezni kívánja a közleményt" (Józsa 1982: 341). A harmadik dimenzió a memóriáé, mely értelmezésében nem más, mint a részletekre való emlékezés mértéke. Szempontunkból érdekesebb a negyedik dimenzió, az automatizmusok és a hagyományok dimenziója, mely két részből tevődik össze, s mely a fentebb ismertetett László-gondolatokhoz kapcsolódik. Ennek első része az osztályozás társadalmi automatizmusa, mely azt jelenti, hogy „[...] a valamely adott kultúrában érvényes osztályozási és megítélési rendszer az ebben a kultúrában élő egyének reflexrendszerévé válik, s esetről esetre jelen van magában a művek hatásfolyamatában" (Józsa 1982: 343). A második részt a verbalitás szupremációja adja, amely „valószínűleg azt jelenti, hogy az embernek a valósághoz való viszonyára és belső világára nagyobb mértékben nyomja rá bélyegét a verbalitás, hogy messzebb került a képek világától, hogy nagyobb mértékben halt ki belőle a képek útján való kommunikálás szükséglete" (Józsa 1982: 344). Józsa tanulmánya 1982-ben íródott, s minden valószínűség szerint érdekes lenne egy ma elvégzett kísérlet a mai kor embereivel - pláne gyerekeivel -, akik a képeknek sokkal nagyobb mértékben vannak kitéve, mint közel negyven évvel ezelőtt. A Józsa által felállított harmadik kategória az esztétikai hatásmechanizmus belülről, mely nem más, mint a befogadás folyamatának leírására alkotott modell. Három momentum különül itt el egymástól időrendi sorrendben. Az első az információátadás folyamata, mely egy háromdimenziós rendszerben megy végbe, melyet három változó határoz meg: az információ típusa, a mű globális jellege és a befogadó intencionalitása, az alkotással szembeni attitűdje. A második lépcsőben a mozgósított reakciók a mérvadóak. Ezek a következők: az azonosulás, az erkölcsi rend integritása, a formaélmény és a valamilyen egyetemes emberi problematikával való találkozás élménye. Az azonosuláson egy olyan emocionális természetű szükségletet ért, melynek lényege, hogy „[...] a befogadó azonosul a hőssel, a helyébe képzeli magát, sikerei és kudarcai az ő sikerei és kudarcai lesznek. Az emocionális azonosulás ezen elsődleges szintje nélkül nincs esztétikai élmény" (Józsa 1982: 347). Az erkölcsi rend, az erkölcsi jóérzés, a biztonság érzésének mozgósítása szintén döntő fontosságú a befogadás folyamatában, $s$ ez sokféleképpen lehet kölcsönhatásban az azonosulással. Jelen kutatásunk szempontjából is nagyon fontos korrelációra irányítja rá a tanulmány a figyelmünket. Érdekes ez abból a szempontból is, hogy az általunk megvizsgált meseátiratok mennyire felelnek meg napjainkban Józsa közel negyven évvel ezelőtti megállapításainak, mely így hangzik: „Valamely adott társadalomban a különböző értékek nem egyformán egyetemesek. Az »olcsó« erkölcsi evidenciákon alapuló esztétikai termék az illető társadalom legegyetemesebb, legkevésbé vitatott értékeinek képviselőivé teszi 
azonosulásra késztető hőseit, és ezáltal nyújtja az olcsó élmény és biztonság lehetőségét. Következésképpen minél bonyolultabb, strukturáltabb a mű, minél inkább az emberi létezés igazi problémáit veti fel, annál inkább nélkülözi a befogadó ezeket az egyszerű és kényelmes lehetőségeket. Minél inkább ellentmond egymásnak a müben jelenlévő tényezőknek ez a két csoportja - azoké, amelyek az azonosulási reakciókat mozgósítják, és azoké, amelyek a befogadót állásfoglalásra kényszerítő értékproblémákat vetnek fel -, annál nehezebb a befogadási folyamat, annál inkább munkát, reflexiót, erőfeszítést követel, hiszen meg kell oldani a mű »szövege« által keletkező ellentmondásokat" (Józsa 1982: 349). Munkánk szempontjából azért sem elhanyagolhatók ezek a megállapítások, mert a modernmese-átiratok befogadása kapcsán arra (is) keressük a választ, miért születnek „olcsó” evidenciákat tartalmazó művek, melyek a befogadótól (jelen esetben a gyerekektől) nem igényelnek különösebb erőfeszítést, illetve miért nevelünk olyan generáció(ka)t, akik csak az olcsó evidenciák felismerésére képesek. Józsa a befogadás folyamatának végső állomásaként a végleges esztétikai ítélet tényezőit sorolja fel, melynek két fajtáját említi. Az egyik az „esztétikai közvélemény” koncentrált pólusa, mely azt jeleníti meg, hogy „[...] egy adott kultúrában [...] működik valamilyen, legalábbis emocionális, mindenesetre elementáris társadalmi konszenzus, oly módon, hogy a magasabb, bonyolultabb szinteken fellépő mindennemű differenciáció, a reakciók és ítéletek mindennemü divergenciája - tendenciálisan - csak ennek a konszenzusnak a határain belül, ennek a talaján lehetséges” (Józsa, 1982. 352.). Másik fajtája az esztétikai ítélet „normatív” és „autentikus” szintjének elkülönülése. Józsa kísérletei azt igazolták, hogy „[... a beivódott esztétikai normák mindenütt elkülönülnek a mű hatása alatt fellépő reális élménytől és konfliktusba kerülhetnek vele, [...] a normativitás és az autenticitás kettőssége általános szabálya az esztétikai alkotásra való reagálásnak" (Józsa 1982: 355).

Halász László egy korábbi kutatása a fenti megállapítást annyiban támasztja alá, hogy szerinte foglalkozni kell az értékelési folyamat pszichológiájával - értékétől függetlenül. A Józsa által megfogalmazott gondolatokat fordított aspektusból közelíti meg. „A pszichológust azonban nemcsak annak megállapítása foglalkoztatja, hogy egyének, illetve csoportok szükségleteik, érdekeik következtében mit tartanak értéknek és mit nem. Feladata annak tisztázása is, ahogyan az egyén vagy csoport eljut a partikuláris érdekeken és helyzeteken túlmutató társadalmi preferenciák és követelmények felismeréséhez, amelyek az értékekben megtestesülnek. Ezért az értékítélet - alkotási folyamat megértése érdekében viszonyítási keretként a társadalmi objektivációk által közvetített értékrend figyelembevételéről sem mondhat le" (Halász 1976: 59). Halász különbséget tesz a mű befogadása közben lezajló és a mű befogadását követő értékelés között. Mivel véleménye szerint az első fajta értékelés vizsgálata pszichofiziológiai kutatásokat igényelne, ezért a kutatók inkább a második fázisra, a műértékelés befogadást követő vizsgálatára fókuszálnak. Halász kiindulópontja ebben az, hogy „[...] pszichológiailag a mű mindenfajta megfigyelése, leírása, értelmezése, megítélése egyben értékelés is" (Halász 1976: 61). Az olvasó azonban értékélményt szerezhet olyan művekből is, melyekben kevés az objektív esztétikai érték. További nehézséget jelenthet az értékítélet megalkotásában, hogy a műalkotások esztétikán kívüli értékeket is magukba olvasztanak. „A művészetnek, illetve az esztétikumnak ez az immanens sajátossága kezére játszik a kevésbé felkészült olvasónak inadekvát értékelő magatartása kialakításában. A művészi érték átélésében sajátos, kétarcú szűrő, átalakító és továbbító szerepet tölthet be a szerzőket és a műveket körülvevő hálózat. Fékező szerepét mutatja, hogy a szerző presztízse a nevével - joggal, jogtalanul - összekapcsolt szöveget, annak tényleges értékétől függetlenül beburkolja. Teszi ezt azért, mert a presztízs tényleges szociális érték" (Halász 1976: 62). Emellett az értékelés során fontos szerepet kapnak a témák, melyeknek önállósult szociális érté- 
kük van. Ezek bizonyítására végezte Halász kísérleteit, melyek során eredeti műveket és azok „hamisított” változatait olvastatta el kísérleti személyekkel. Azért két művet választottak a kutatók, mert az egyik felépítése hagyományosabb, egyszerúbben követhető volt, a másiké formabontóbb. Jelen kutatásunk szempontjából fontos kitérnünk arra is, hogyan készültek a nem szerző által készített szövegek. „A hamisított változatok elkészítése során több mozzanat jöhet számításba, amely a művet szokványosabbá, tompítottabbá, egysíkúbbá teszi, egészen odáig, hogy jelentése az eredetitől már nemcsak eltérő, de homlokegyenest ellenkező lesz. E mozzanatok közül elsősorban az ábrázoló és kifejező erő csökkentésével, a feszültség csökkentésével, a motívumok egy részének elhagyásával, elszemélytelenítéssel, happy endesítéssel, magyarázkodó megjegyzések beiktatásával, divatos sztereotípiák és sematikus elemek bevitelével végeztük - a terjedelem megtartásával - átalakításokat" - vallja Halász (Halász 1976: 66) a több mint negyven évvel ezelőtt elvégzett kísérlet kapcsán. A modern meseátirat-fajták is pontosan ezeket az átalakításokat tartalmazzák. A több évtizeddel ezelőtti válaszokból kiderül, máshogy érvényesült az értékfelismerési tendencia a hagyományos felépítésű és a formabontó irodalmi műveknél. Az 1983-ban megjelent Művészetpszichológia című könyv szerkesztője szintén Halász László volt, s e kötetben magyar fordításban is megjelent Louis A. Moffet „Műalkotások mint személyek: a művészetpszichológia új iránya” című tanulmánya, mely némiképp a fent idézett kutatás személyiségfüggő voltát látszik igazolni. Moffet abból a feltételezésből indul ki, hogy a műalkotásokat felfoghatjuk személyekként is. „A művész teremtő tevékenységét már régóta szülési folyamatnak nevezik, és a müvész által létrehozott műalkotásokat szívesen nevezik a művész gyermekeinek" (Moffet 1983: 414). Arra a következtetésre jut, hogy a „hasonló hasonlót vonz” elve érvényesül a műalkotások befogadása során, csakúgy, mint a társadalmi összehasonlítási folyamatokban, ahol az emberek olyan személyeket választanak társnak, akik hasonlítanak hozzájuk. Ennek alapján Moffet azt állítja, hogy „a műalkotások észlelése vagy értelmezése várhatóan a műalkotás tetszésével és a befogadó énjéhez viszonyított hasonlóságával van összefüggésben" (Moffet 1983: 418).

Éles Csaba (2007) is hasonlóan gondolkodik, amikor arról beszél, hogy a műalkotások befogadására fel kell készülnünk, ami „[...] elsősorban lelki és mentális jellegű. Az embernek le kell vetkőznie bizonyos előítéleteit, meg kell szabadulnia mindazon ellenérzéseitől, elutasító beidegződéseitől, amelyek az adott szerzővel vagy előadóművésszel, egy múfajjal vagy a terjedelemmel, egy stílussal, egy technikával vagy éppen egy hangszerrel kapcsolatosak. A befogadónak - saját élvezete elősegítésére - bizalmat és rokonszenvet kell megelőlegeznie elsősorban a művel, de annak többé-kevésbé teljes kulturális, szociális és politikai szövegkörnyezetével szemben is. Minél erőtlenebb egy befogadói szándék, mindezek annál inkább magasodnak korlátokká. Viszont minél erőteljesebb a kontaktusra való törekvés, ezek a körülmények annál inkább szolgálják az élmény hatásfokát és tartósságát, izgalmát és jó emlékét" (Éles 2007: 16). Ugyanezt támasztja alá Halász László (1972) kutatása is, aki megfigyelte, hogy „[...] a mű felfogásának már kezdetekor a művész nevéhez mint hívószóhoz társuló hálózat megmutatja azt a helyet, amelyet a mű az adott egyént (pro vagy kontra) viszonyítási adatokkal ellátó alakulatokban: tankönyvekben, hivatalos kritikákban, az iskola, az egyetem oktatóinál, helyi vélemény-irányítóknál, a baráti, a családi kör tagjainál stb. elfoglal" (Halász 1972: 438). Ezek szerint azt mondhatjuk, hogy egy műről korábban szerzett információ már előzetesen kialakít egy attitűdöt, amely alapján egy adott művet megítélünk. De talán pont ezért van könnyebb dolgunk viszonylag kicsi gyerekek körében végzett felmérés során, mivel nincs prekoncepciójuk. A müalkotás - jelen esetünkben a mese - által kiváltott esztétikai reakciót keressük tehát, melynek alapját Lev Vigotszkij (1968) szerint „[...] a művészet által keltett affektusok 
képezik, amelyeket teljes valóságukban és teljes erejükben átélünk, amelyek azonban a fantáziának abban a tevékenységében jutnak el kisülésükig, amelyet a művészet észlelése mindannyiszor megkövetel tőlünk. Ezen centrális kisülés folytán az affektus külső motoros oldala rendkívül legátolódik és lefojtódik, s úgy tűnik fel számunkra, hogy csak vélt érzelmeket élünk át. Az érzelemnek és a fantáziának éppen erre az egységére épül minden művészet" (Vigotszkij 1968: 347). Érdekes lehet megemlíteni itt, hogy 1980-ban Siklaki István Elbeszélő szövegekkel kapcsolatos kutatások című kötetében több különböző modellt is áttekint. Központi kérdése az, hogyan értjük meg (vagy félre-) a szövegeket. Az általa felsorolt szerkezeti modellek (például Proppé, Colbyé vagy Rumelharté) azonban csak addig jutnak el, hogy fóként a szerkezet (és elvétve a nyelvtan) szintjén keressék a megértés kulcsát, azonban az érzelmeknek és a fantáziának semmi szerepet nem szánnak. Ebben a lassan negyven évvel ezelőtti korszakban született Tibori Tímea (1986) Az esztétikai befogadás vizsgálata című munkája is, mely több helyen is használja a „megértés vagy befogadás” kifejezést, egyenlőségjelet téve a két fogalom közé az irodalmi befogadás vizsgálatok során, melyeket interjúk segítségével végeztek. Ezt támasztja alá, hogy az 1980-as években végzett kutatás arra a következtetésre jutott, hogy a megértésnek különböző szintjei vannak, melyek a kutatásban részt vevő kísérleti személyek műveltségbeli, háttérismereti szintjétől függnek, vagyis „[A]z irodalmi mű befogadása megfelel egy tanulási és ismeretszerzési, ismeretbeépítési folyamatnak, így az interjúk felfoghatók egy projektív vizsgának, vizsgaszituációnak" (Tibori 1986: 100)

Napjainkban is találkozunk hasonló, pedagógiai vonatkozású megközelítéssel, különösen a tanórai tevékenységek kapcsán. H. Tóth István (1994) szerint „[...] az olvasó az örömeit, a bánatát, vívódásait, töprengéseit, önmagát, az életét keresi a müben, hogy emberi teljességét erősíthesse. Vajon szem előtt tartjuk-e tantárgypedagógiánkban az olvasó autonómiáját, az értelmezés szabadságát, sokszínű lehetőségeit?" (H. Tóth 1994: 92). Hasonló aggodalmakról ír Tóth Beatrix (2013) is, aki szerint „[...] kulcsfontosságú kérdés az, hogyan foglalkozzunk az irodalmi szövegekkel. Ennek kapcsán szembe kell néznünk egy sajátos ellentmondással. Az iskolai gyakorlatban a szépirodalmi szövegek feldolgozása a tanító által irányított folyamatban zajlik. Többnyire ő mutatja be a meséket, elbeszéléseket, majd kérdéseket tesz fel, melyek segítségével elemzik, megbeszélik az olvasmányt. Lássuk be, ez teljesen másfajta olvasási módja az irodalmi szövegeknek, mint ahogy az iskolán kívül foglalkozunk velük. Mondhatni nem rendeltetésszerü használatról van szó. Hiszen általában mi magunk olvassuk el azokat a szövegeket, amelyeket mi választottunk, és nem kell közben vagy utána mások kérdéseire válaszolnunk. Azért olvasunk, mert élvezzük az olvasást, mert olvasni jó" (Tóth 2013: 13). Kutatásunkban mi is inkább azt az élményt szerettük volna megragadni, melyet a gyerekek egy nekik elolvasott klasszikus mese és annak modern párja mesélése közben szereztek, és nem arra voltunk kíváncsiak, hogy az általunk esetlegesen megfogalmazott kérdésekre - amelyekről mi gondoljuk, hogy a befogadás szempontjából fontosak - milyen válaszokat adnak.

\section{A mesekategóriák}

A modern meseátiratok száma szinte végtelen, azonban mutatnak csoportonként hasonlóságokat, így a felméréshez választott mesepárok ezeket szerették volna reprezentálni. A meseátiratokat az empirikus vizsgálatok előtt eredeti párjukkal együtt morfológiai egységekre, azaz a legkisebb jelentéssel bíró egységekre bontottuk, majd a klasszikus történetet és a modern átiratot egymás mellé rendeztük. Az így kapott meseelemeket ezt követően abból a szempontból vizsgáltuk meg, milyen mértékben van köztük egybeesés, ha van ilyen (Kopházi-Molnár 2016). Az olyan mesét, ahol a két történet cselekménye követte egymást, és az egybeesés a legnagyobb értéket mutatta (42\% teljes és 18\% rész- 
leges), 'tökéletesen fedő' átiratnak neveztük el. Ez jelen esetben Hófehérke és a hét törpe, illetve Rodari Igazgató és könyvelő, avagy az autó, a hegedű és a versenyvillamos című meséje volt. Amikor egy klasszikus történet adja az alapot, és egy abból készült átirat a modern mese, a 'klasszikus történet átírása' nevet kapta. Az ehhez választott szöveg a Lamb testvérek Hamlet-meséje, illetve Az oroszlánkirály. A könyvesboltokban gyakran látható az a fajta 'rövidített átirat', amikor a klasszikus történet igencsak leegyszerűsödik. E két utóbbi típusnál viszonylag csekély az egyezés, a klasszikus átiratában összesen 19\%, míg a rövidített mesében 23\%. Itt az összehasonlítást a Pirosbúbocska és a Piroska és a farkas című rövidített történetén végeztük el. A negyedik típus a 'redundáns mese', mert ez mintegy továbbfüzi az eredeti mese történetét, és egy olyan epizódjellegű történetet hoz létre, mely az ismert szereplőkkel történik ugyan, de az eredeti meséhez csak a mese miliője köti. Ehhez a választott mese a Hamupipőke, illetve a Hamupipőke - az egerek lakomája volt. Az ötödik kategória a 'hiperkorrekció', mely a főbb motívumoknál viszonylag jelentős egyezést mutat, de itt a mese vége - s így pont a lényeg - új értelmezést kap. Itt az elemek több mint harmada egyezett. Ebben a kategóriában a Békakirály és Vashenrik, illetve a Békakirályfi című mesét vetettük össze. Az utolsó kategóriában található mese is hasonló arányban illeszkedett egymáshoz, mivel a túlmodernizált átirat is 37\%-ban mutatott egyezést. Ehhez A szélkötő Kalamonát, illetve Kamarás István Kalamona kalamajkáját elemeztük. A mesepárok egyezésének százalékban kifejezett értékei természetesen nem érvényesek minden átiratra, de a mesepártípusok egymással való összevethetősége érdekében szükség volt erre, s ezt az alábbi ábrán is szemléletesen láthatjuk (1. ábra). Ezt a hat mesepárral reprezentált kategóriát használtuk kisgyerekek körében a mesehallgatás során szerzett élmény mérésére.

1. ábra: Egyezés a morfológiai elemek között, illetve azok hiánya a különbözô átirat típusok esetén. A: tökéletesen fedő átirat; K: klasszikus történet átírása; R: rövidített átirat; E: redundáns átirat; H: hiperkorrekciós átirat; T: túlmodernizált mese (saját szerkesztés)

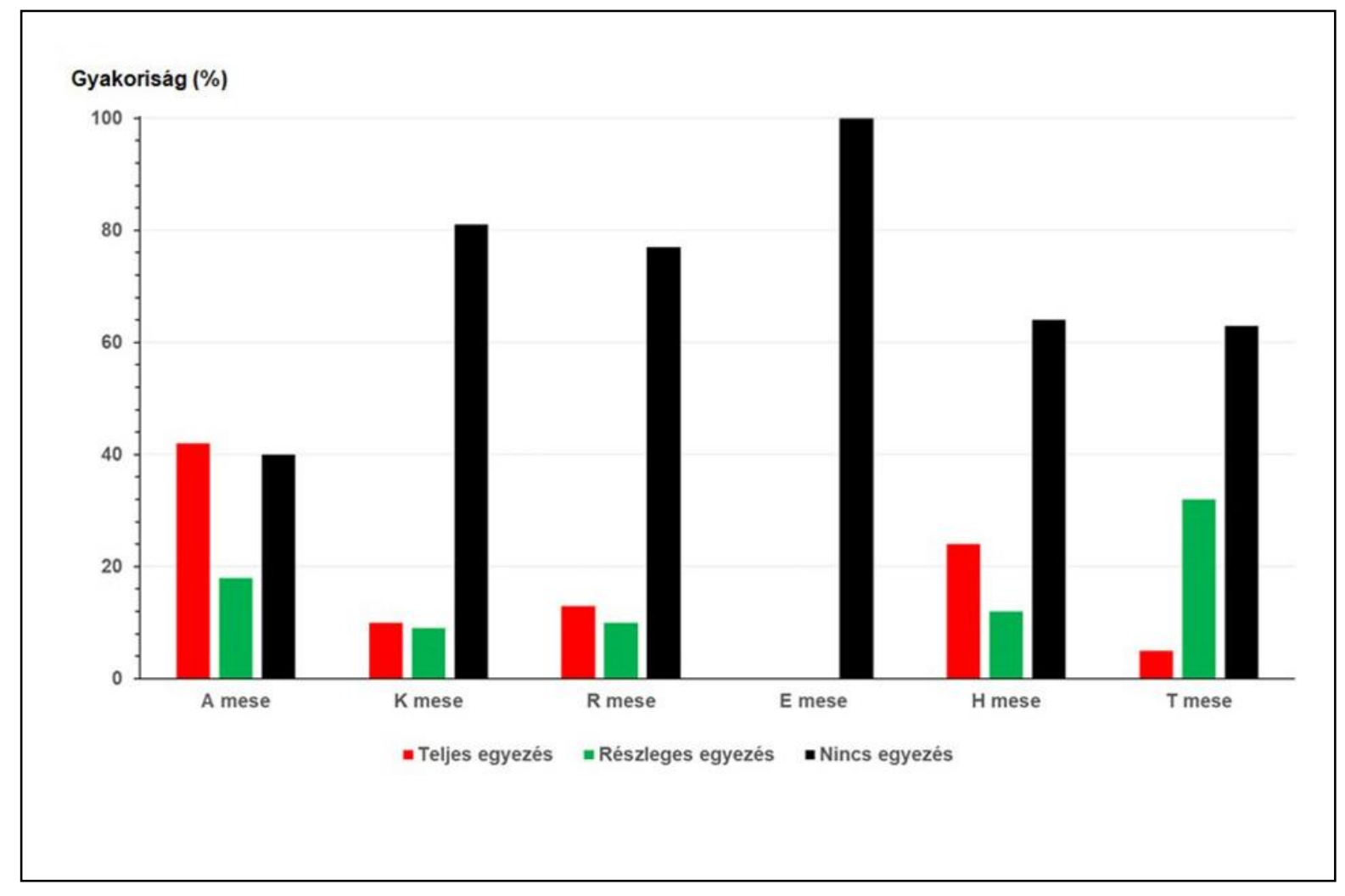




\section{A módszer}

A korábbi évszázadokban több kutató próbálkozott már szabad asszociációs módszer kidolgozásával, a jelen kutatás azonban egy újabb keletű módszerre támaszkodik, melyet Lorand B. Szalay és James Deese (1978) fejlesztett ki és tett közzé a Subjective Meaning And Culture: An Assessment Through Word Associations (Szubjektív jelentés és kultúra: felmérés szóasszociációkon keresztül) című munkájában. Eredetileg a szabad asszociációs módszert a különböző kulturális különbségek feltárására használták, azonban könyvük záró fejezetében a szerzők maguk is elismerik, hogy szisztémájuk más területeken is használható. Az asszociációval szubjektív jelentés válik elérhetővé az empirikus vizsgálat számára. Tükrözik percepcióink, hiedelmeink és attitűdjeink struktúráját, és további előnye, hogy minimalizálja a kérdező közbeavatkozását. A szerzők szerint „az asszociációk függetlenek a kommunikációs szándéktól, hogy valami sajátos, szervezett diskurzust folytassunk. Ezek egyszerűen a gondolatok kifejezői. Ez az, ami egyedivé és hasznossá teszi őket. Nyilvánvalóan egyszerűbb, ahogy azt a szabad asszociáció legrégebbi kutatói is felfedezték, kifejezni gondolatainkat, amikor a szavak közötti kapcsolatokat nem kötik a szintaxis és a morfológia szabályai" (Szalay-Deese 1978: 16)

\section{Az elővizsgálat és a tesztelő kutatások}

Első körben elővizsgálatot végeztünk. Többféle asszociációs technikára épülő módszer is ismert, melyek közül úgynevezett asszociációs csoportanalízist használtuk a gyerekek körében végzett felmérésnél. Technikailag ez annyit jelentett, hogy a Dunántúl különböző településtípusaiban (nagyobb városaiban, kisvárosaiban, illetve falvakban) tanító pedagógusokat kértünk fel ennek lefolytatására. A célunk az volt, hogy fóként második osztályos (tehát már az írás készségét elsajátított) tanulók írják le azokat a szavakat, kifejezéseket, melyek annak apropóján jutottak eszükbe, hogy miért tetszik nekik a mese. A tesztelés anonim módon történt, és összesen 373 olyan papírlapot eredményezett az elővizsgálat, melyeken a gyerekek által felsorolt elemek szerepeltek. A megkérdezettek időkorlát nélkül írhatták le, ami eszükbe jutott. Ezt követően a válaszok számítógépen rögzítésre kerültek. Itt némi nehézséget csak az okozott, hogy el kellett dönteni, mi számít szinonimának (például a „vannak benne állatok” kifejezés szinonimájaként értékeltük azokat a megjegyzéseket, amelyeket egy konkrét állat mesebeli szerepéről írtak: „van benne kutya”, „van benne ló” stb., vagy ilyen kifejezéseket, mint: „felvidít”, „nem leszek tőle szomorú"). Így keletkezett egy 233 itemből álló lista, melyet ezt követően öt „kódoló” kapott meg. Feladatuk az volt, hogy sorolják csoportba az összetartozó koncepciókat, melyeket Szalay és Deese „jelentéskomponenseknek” nevez. A kategóriáikat el kellett nevezniük, és azokból nem lehetett több mint tizenkettő. Ennek eredményeként született meg egy összehasonlítási alap, melyhez a későbbiekben a mesepárok olvasása során kapott eredményeket hasonlítottuk.

Összesen kilenc kategória született, az elnevezésük pedig az alapján történt, melyik elnevezést adta a legtöbb kódoló. Végül a következő megoszlásban láthatjuk a kategóriákba sorolt megjegyzéseket: a szereplőkre vonatkozó megjegyzések (20\%), a befogadóra gyakorolt hatás (18\%), a közvetítő médiumra vonatkozó megjegyzések (15\%), a cselekményre vonatkozó megjegyzések (13\%), a mesék jellemzői, feladata (13\%), a nem reális tartalmakra vonatkozó megjegyzések (8\%), az esztétikai élményre vonatkozó megjegyzések (7\%), a helyszínekre vonatkozó megjegyzések (3\%) és az 'egyéb' kategória (3\%). Ha végignézünk az első nyolc elemen (vicces, izgalmas, érdekes, szép), akkor elmondhatjuk, hogy az általunk felmért gyerekek számára legfontosabb az, milyen hatást gyakorol rájuk a mese, hisz a fenti felsorolásból négy elem (vagyis a fele) a befogadóra gyakorolt hatás kategóriájába tartozik. Ebből következik, hogy a mai gyerekeknek is na- 
gyon fontos a szórakoztatás, az izgalom, az érdekesség, ami arra enged következtetni, hogy a szórakoztató, modernizált meseátiratok mindenképpen elnyerik majd tetszésüket (Kopházi-Molnár 2015).

A befogadásvizsgálatokat megelőzően tesztelő kutatások elvégzésére került sor. $\mathrm{Az}$ első egy technikai jellegű próbálkozás volt, melynek során arra voltunk kíváncsiak, milyen hosszú ideig tudnak figyelni a gyerekek. Négy második osztályos diák (két kisfiú és két kislány) folyamatosan hallgatta a meséket, és közben a tetszést is beírták különböző színnel megjelölt hőmérőkre, amely gyakorlatilag egy 0-5-ig terjedő, hatfokozatú skála. Azt is leírták, mi jutott eszükbe a tetszés kapcsán. Ez körülbelül két és fél órát vett igénybe, és természetesen nagyon elfáradtak a végére. Az is nyilvánvalóvá vált az első mérési próbálkozás során, hogy a megkérdezettek kedvelik a modern, vicces, szórakoztató történeteket, ugyanakkor viszonylag sok megjegyzést írtak az eredeti mesékről, lényegesen többet, mint a modern párjukról. Azt is láthattuk továbbá, hogy a gyerekeknek nagyon fontos a képi megjelenítés. Élvezték ugyan a mesefelolvasást, ennek ellenére azt kérték, hogy mutassunk neki illusztrációkat is a mesékhez. A második tesztelés során nagyobb mintát használtunk, összesen kilencven kisgyerek vett benne részt. Kiválasztottunk a hat fent nevezett mesepárból egyet (nevezetesen a teljesen átfedő mesét), és először harminc második osztályos gyereknek (tizenöt fiú és tizenöt lány) elmeséltük a klasszikus történetet. Ezt követően elmeséltük harminc tanulónak (tizenöt fiú és tizenöt lány) a modern párját. Ebben a felmérésben természetesen nem vettek részt azok a gyerekek, akik egy hónappal korábban az első tesztelő mérésben már segítségünkre voltak. Következő lépésként mindkét történetet együtt meséltük el egy másik iskolában szintén harminc másodikos tanulónak (tizenöt fiú és tizenöt lány). A gyerekek a történetek meghallgatása után mindhárom alkalommal egy hőmérőn jelölték, mennyire tetszett nekik a mese, illetve szabad asszociációval azt is leírták, felsorolták, mi tetszett nekik a mesében. Ebben a tesztelő kutatásban arra voltunk kíváncsiak, hogy hatnak egymásra a mesék, befolyásolják-e az ítéletet, ha nem külön-külön, hanem egymás után hallják a történeteket. Ez azért volt fontos, mert tudni szerettük volna, hogy a további mérések során tudjuk-e együtt mesélni az eredeti és az átírt történeteket, vagy azokat külön kell megtenni. Az alábbi táblázat (1. táblázat) foglalja össze az eredményeket, melyek a tesztelő kutatások során születtek, s mely alapján három következtetést tudtunk levonni:

1. A modern mese jobban tetszett, mint a klasszikus $(332>287)$

2. Nincs jelentős különbség „külön” (169 vs. 163, illetve 141 vs 146) és „együtt” között. A jobban tetsző modern mese minimálisan kontaminálja („javítja”, tetszőbbé teszi) az egyébként kevésbé tetsző klasszikus mesét (146 vs 141).

3. Alapvetően tetszenek a mesék, hiszen a maximális tetszést jelentő $(30 \times 6)=180$ pontot jól megközelíti a „lerontatlanul” külön hallgatott modern mese 169 pontja.

Az első tesztelés során két dolog látszott, mely a későbbi méréssel összevethető: az egyik az, hogy a modern mese nagyobb tetszést aratott, a másik pedig az, hogy a gyerekek a felső értékeket adták inkább a meséknek (azaz 3-5), mint az alsó értékeket (azaz 0-2). Láthatóvá vált az is, hogy az eredeti történet és a modern átirat nem zavarja egymást, így a mesepárokat ezt követően ugyanazoknak a gyerekeknek meséltük el egymás után.

1. táblázat: A tesztelő mérés eredményei (saját szerkesztés)

\begin{tabular}{|l|l|l|l|l|l|l|}
\hline & $\begin{array}{l}\text { modern } \\
\text { külön }\end{array}$ & $\begin{array}{l}\text { modern } \\
\text { együtt }\end{array}$ & $\Sigma$ & $\begin{array}{l}\text { klasszikus } \\
\text { külön }\end{array}$ & $\begin{array}{l}\text { klasszikus } \\
\text { együtt }\end{array}$ & $\Sigma$ \\
\hline 1. kategória (0) & 1 & & 1 & 4 & 2 & 6 \\
\hline
\end{tabular}




\begin{tabular}{|c|c|c|c|c|c|c|}
\hline 2. kategória (1) & & & & 1 & & 1 \\
\hline 3. kategória (2) & 1 & 4 & 5 & 2 & & 2 \\
\hline 4. kategória (3) & 1 & 2 & 3 & 1 & 5 & 6 \\
\hline 5. kategória (4) & 1 & 1 & 2 & 7 & 14 & 21 \\
\hline 6. kategória (5) & 26 & 23 & 49 & 15 & 9 & 24 \\
\hline$\Sigma$ & 30 & 30 & 60 & 30 & 30 & 60 \\
\hline $\begin{array}{l}\text { súlyozott score } \\
\text { összege }\end{array}$ & 169 & 163 & 332 & 141 & 146 & 287 \\
\hline
\end{tabular}

\section{A befogadásvizsgálatok skálán mért értékei}

A vizsgálatokat hat alkalommal, hat különböző iskolában végeztük. Mivel a tesztelő kutatások során már jártunk egy olyan iskolában, ahol a klasszikus és a modern mesét együtt hallgatták a gyerekek, így ezt a mesepárt már nem ismételtük. A gyerekek a meghallgatást követően egy lapot kaptak, melynek egyik oldalán megjelölték a nemüket, majd felsorolták, mi tetszett a mesében. A lap hátoldalán találtak hat színes hőmérőt, melyből egyet megjelölve nyilvánítottak véleményt a tetszés fokáról. A hat hőmérő nem volt más, mint egy hatfokozatú skála, 0-5-ig különböző színárnyalatokkal jelölve a kéktől (hideg szín - nem tetszik) a pirosig (meleg szín - tetszik), ami a kisgyerekek könnyebb eligazodását szolgálta. Elsőként az eredeti történetet ismerték meg, s hőmérőn jelölték a tetszést. Utána kifejezéseket, szavakat írtak azzal kapcsolatban, hogy mi tetszett nekik a mesében, majd a modern mese meghallgatása következett, mellyel ugyanezt a mérést végeztük el. Minden meseolvasást követően a gyerekek kézfeltartással jelölték, ismerték-e már a mesét, amelyet hallottak. A hat helyszínen összesen száznyolcvan kisiskolás vett részt a felmérésben. Mivel mindenki két mesét hallgatott, így háromszázhatvan felmérő lapon született eredmény. Először a skálán mért tetszést értékeltük ki statisztikai programmal. Minden lap egy kódot kapott. Az egyes mesetípusba tartozó meséket egyegy betű jelölte, a klasszikus történetet mindig egyes számmal, a modern változatot kettessel számoztuk, majd az F (fiú) vagy az L (lány) a nemeket jelölte 1-15-ig számozva. Az egyes mesetípusok olyan betűt kaptak, amelyből könnyen felismerhetőek, így A-val jelöltük az átfedő átiratokat, K-val a klasszikus történetet, E-vel az epizódot betoldó redundáns mesét, $\mathrm{H}$-val a hiperkorrekciós verziót, T-vel a túlmodernizáltat, R-rel pedig a rövidített történetet. Így tehát három változót tartalmazott a kód, ami alapján az információt rögzítettük. IBM SPSS Statistics 22 program segítségével elemeztük az eredményeket, majd diagramok készültek az eredmények még könnyebb átláthatósága érdekében. Khinégyzet-elemzés alkalmazásával megvizsgáltuk, hogy a változók között van-e összefüggés. Az általunk vizsgált három változó, vagyis a nemek, a mesetípusok, illetve a mesekategóriák szignifikanciáját mutatja a 2. táblázat, melyből kitűnik, hogy mindhárom változó esetében a szignifikanciaszint $5 \%$ alatti értéket mutat, ami azt jelenti, hogy a szokásos 95\%-os biztonság mellett a nullhipotézist elvethetjük, tehát a változók között van összefüggés. 
2. táblázat: A változók szignifikanciája

\begin{tabular}{|c|c|c|c|}
\hline Forrás & Ratio Chi-Square & $\mathrm{df}$ & Sig. \\
\hline (Intercept) & 825,670 & 1 &, 000 \\
\hline Nem & 15,896 & 1 &, 000 \\
\hline Típus & 11,934 & 1 &, 001 \\
\hline Mese & 20,689 & 5 &, 001 \\
\hline
\end{tabular}

Elsősorban arra voltunk azonban kíváncsiak, hogy van-e szignifikáns különbség a klasszikus és a modern mesék tetszése között. $\mathrm{A} \mathrm{H}_{0}$ vizsgálatának eredménye azt mutatja, hogy a klasszikus és a modern mesék összevetése esetén van szignifikáns különbség a két mesecsoport között. Tehát ez esetünkben a $\mathrm{H}_{1}$ érvényességét támasztja alá. Ebben az esetben a mesetípus a független, a klasszikus és a modern kategóriák pedig a függő változó. Az eredmények vizsgálata, a kéttényezős variancia-analízis ismétlések nélkül, a következő ábrán (2. ábra) látható diagramot eredményezte:

2. ábra: A skálán mért tetszés a két mesetípus alapján. H: hiperkorrekciós mese, K: klasszikus történet, A: átfedő történet, E: redundáns mese, R: rövidített történet,

T: túlmodernizált mese

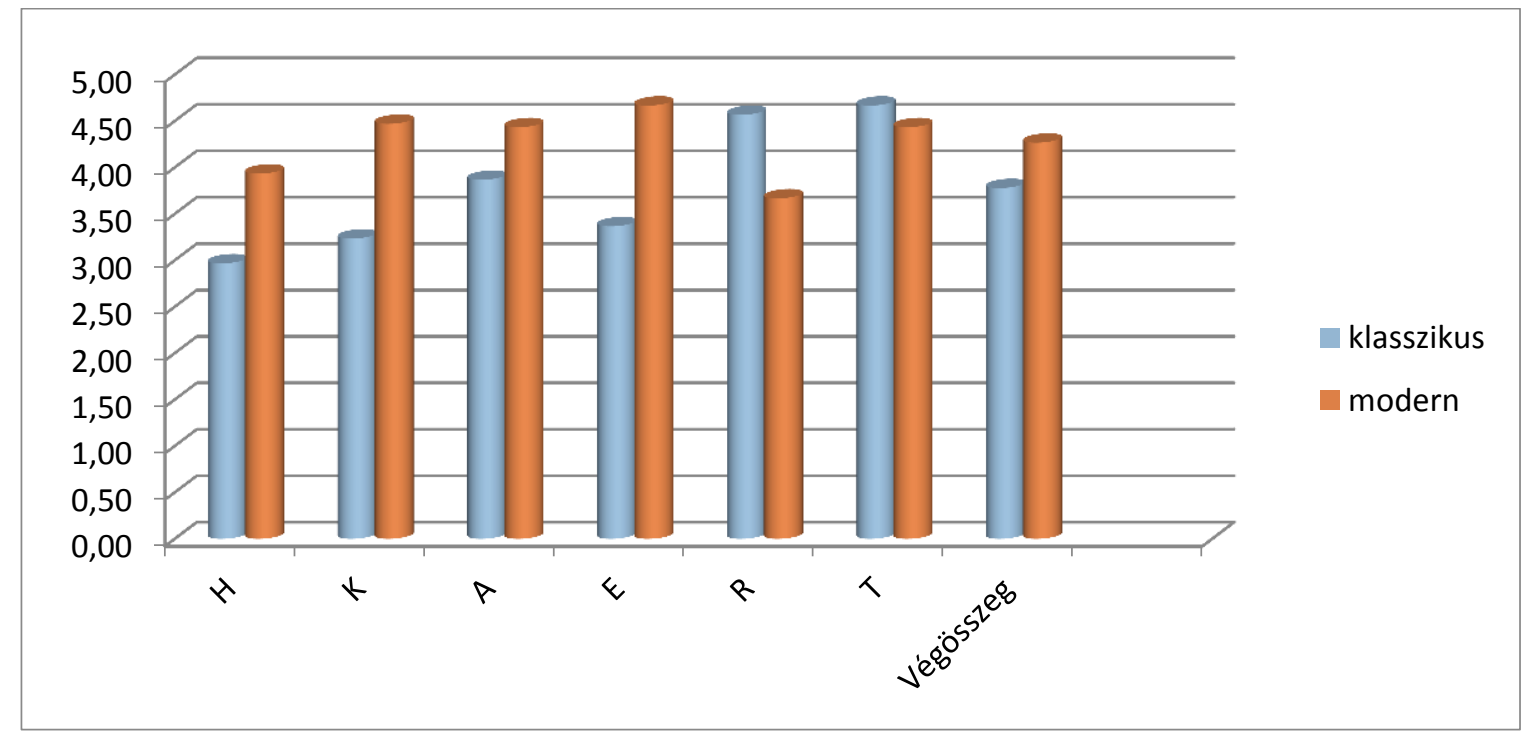

A kéttényezős variancia-analízis ismétlések nélküli vizsgálata a fiúk és a lányok preferenciáit tekintve az alábbi diagramon látható (3. ábra). Itt a független változó a mesék típusa, míg a függő változó a gyerekek neme. 
3. ábra: A mesék skálán mért tetszése nemek és mesetípusok szerint. H: hiperkorrekciós mese, K: klasszikus történet, A: átfedö történet, E: redundáns mese, $R$ : rövidített történet, $T$ : túlmodernizált mese.

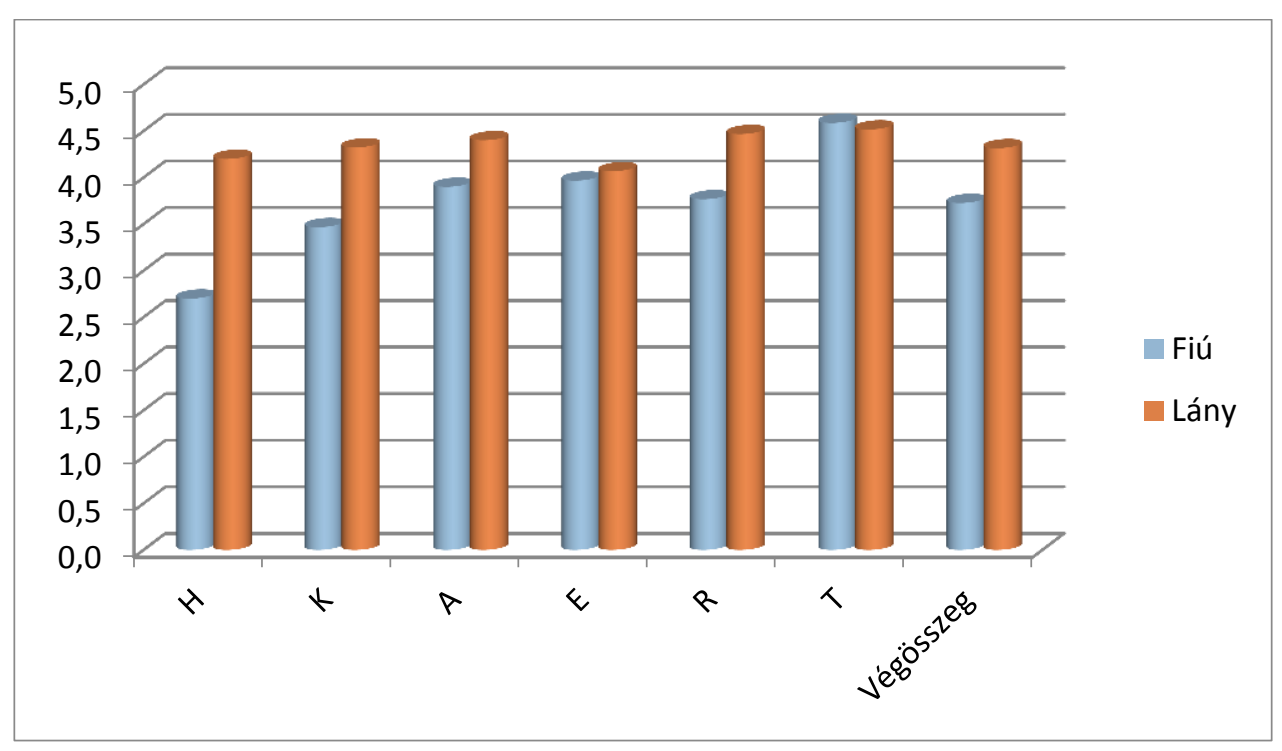

Az ábra azt mutatja, hogy van különbség a fiúk és a lányok válaszai között a skálán mért tetszés alapján. A lányoknak a túlmodernizált mese kivételével jobban tetszettek a mesék, mint a fiúknak, bár az értékek alapján elmondható, hogy a lányoknak is ez tetszett a legjobban. Viszonylag nagy különbség figyelhető meg a hiperkorrekciós mese és annak eredeti története esetében, ami valószínűleg a fiúk által „lányosnak” ítélt, modern történet számlájára írható. Nem lehet ez véletlen, hisz ez a mese egy Barbie-könyv. A válaszok tehát azt sugallják, hogy a lányok kedvelték jobban a meséket a túlmodernizált mese kivételével, ahol egy eddig számukra ismeretlen mesepárral találkoztak egy olyan történet kapcsán, melynek főhőse egy felnövekedő fiú, illetve egy 'nyomozós' történet, mely feltételezhetően a fiúkhoz állt közelebb.

\section{A befogadásvizsgálatok írásbeli válaszai}

Az elővizsgálat során már láthattuk, hogy a gyerekek nagyon sok dolgot soroltak fel, amelyek azzal kapcsolatosak, mitől is tetszenek nekik a mesék. Ugyanezt a kategorizálást elvégeztük a mesékre adott válaszok esetében is, ennek terjedelme azonban meghaladja a jelen tanulmány kereteit, így most csak az összes megjegyzés számát hasonlítjuk össze. A könnyebb áttekinthetőség és összehasonlíthatóság kedvéért a mesékhez füzött megjegyzéseket a skálán mért tetszés értékei mellé rendeztük.

3. táblázat: Összehasonlító táblázat a klasszikus és a modern mesékre adott értékek, illetve az írásbeli válaszok alapján. H: hiperkorrekciós mese, K: klasszikus történet, A: átfedő történet, E: redundáns mese, $R$ : rövidített történet, T: túlmodernizált mese. k: klasszikus mese; m: modern mese (saját szerkesztés)

\begin{tabular}{|l|l|l|l|l|}
\hline Mesetípus & Klasszikus & Modern & Skálán mért átlag & Megjegyzések száma \\
\hline $\mathrm{T}$ & 4,7 & 4,4 & 4,55 & $478(\mathrm{k}: 353+\mathrm{m}: 125)$ \\
\hline $\mathrm{A}$ & 3,9 & 4,7 & 4,2 & $374(\mathrm{k}: 194+\mathrm{m}: 180)$ \\
\hline $\mathrm{R}$ & 4,6 & 3,7 & 4,15 & $188(\mathrm{k}: 105+\mathrm{m}: 83)$ \\
\hline $\mathrm{E}$ & 3,4 & 4,7 & 4,05 & $129(\mathrm{k}: 58+\mathrm{m}: 71)$ \\
\hline $\mathrm{K}$ & 3,2 & 4,5 & 3,85 & $130(\mathrm{k}: 52+\mathrm{m}: 78)$ \\
\hline $\mathrm{H}$ & 3,0 & 3,9 & 3,45 & $214(\mathrm{k}: 131+\mathrm{m}: 83)$ \\
\hline
\end{tabular}


A hőmérőn - azaz a skálán - mért értékek szinte ugyanazt tükrözték, mint az előkutatás eredményei. Mindkét típusú, tehát az eredeti és az átírt történeteket is inkább magasabb értékkel látták el, vagyis a mesék inkább a 'tetszés', mint a 'nem tetszés' kategóriájába estek.

Az egy táblázatba rendezett összes mesére adott választ áttekintve azonban ellentmondásokat is felfedezhetünk. A hőmérőn mért értékek és a mesékhez füzött megjegyzések nem ugyanazt a sorrendet eredményezték. Az élő szóval történő mesélés során több megjegyzést füztek az eredeti történetekhez, míg a hőmérőn azt jelezték, hogy a modern mese tetszett inkább. A gyerekek a hőmérőn mért tetszés alapján a túlmodernizált és a rövidített történet kivételével - vagyis nem az összes esetében - állították azt, hogy a modern történet tetszett inkább. Az írásbeli válaszok alapján azonban más is láthatóvá vált. A túlmodernizált mese esetén, a skálán mért tetszéstől eltérően (mivel ott csekély különbség volt az eredeti történet javára), a hagyományos meséhez közel háromszor annyi megjegyzést fűztek, tehát fantáziájukat ez mozgatta meg jobban, több minden nyerte el ebben a tetszésüket. Az átfedő mese jóval kiegyenlítettebb képet mutatott az asszociációs felmérésben, bár az elemek száma az eredeti történet esetében itt is egy kicsivel ugyan, de több, mint a modern esetében. A rövidített történetnél szintén ezt tapasztalhattuk, bár ez a tetszési skálán is a klasszikus történet iránti preferenciát mutatta. A redundáns átirat esetén a hozzá füzött megjegyzések száma egy kicsivel több, mint amit az eredetihez írtak, bár a befogadóra gyakorolt hatással kapcsolatos megjegyzések a modern történettel kapcsolatos hiányérzetükről tanúskodtak. A klasszikus történet átdolgozása kapcsán a modern történet esetében említettek több mindent, ez tehát egybeesik azzal, amit a hőmérőn is jeleztek. Az utolsó helyen szereplő hiperkorrekciós átirat is kissé ellentmondásos, hisz a klasszikus történethez jóval több megjegyzés társult, mint a modernhez, mégis első benyomásként a modern tetszett inkább. Ha az öszszes megjegyzést nézzük, akkor viszont azt láthatjuk, hogy a hőmérőn mért értékek alapján a tetszési sorrend: T A R K E H, míg a hozzájuk füzött megjegyzések azt mutatják, hogy a leginkább mondandót kiváltó történetek sorrendje: T A H R K E. Vagyis a túlmodernizált mese vezet továbbra is, de annak eredeti története jobban megmozgatta a gyerekek fantáziáját, mint a modern. Az átfedő átirat mindkét felmérés során a második, és egy picivel itt is több a klasszikus mesére írt visszajelzések száma. A hiperkorrekciós mesénél is elég egyértelmű, hogy az eredeti történet volt az, ami inkább arra késztette a gyerekeket, hogy füzzenek hozzá megjegyzést, csakúgy, mint a megrövidített történet kapcsán. A klasszikus történet átirata esetén a modernre írtak többet, és érdekes módon ez történt a redundáns esetében is, amely itt az utolsó helyre szorult.

Az ellentmondás tehát továbbra is fennáll: a gyerekek a hőmérőn mért tetszés szerint a modern történetekhez vonzódtak inkább, míg az élő szóban előadott mesélés sokkal több hozzáfüzni valót váltott ki belőlük főként az eredeti történetek kapcsán. Ebből úgy tűnik, hogy míg az elővizsgálat során a gyerekek fejében sok különböző csatornán érkező történet is szerepelt, addig az élőben előadott történetek a klasszikus mesék felé húzták a válaszokat. A hőmérőn egy első benyomást jelöltek a gyerekek, ezért még azt is meg lehet kockáztatni, hogy - az ő szavaikkal: - „menőbbnek” ítélték meg, ha egy modern történetet kellett értékelniük, mint egy hagyományos mesét. Azonban a fantáziájukat úgy tűnik, hogy nem lehetett becsapni, mert sokkal több mindent írtak a klasszikus történetről, mint a modernről. Ha most azt is megnézzük, hogy melyik mesét ismerték már korábban, akkor a legismertebbtől a legkevésbé (egész pontosan egyáltalán nem) ismert meséig a sorrend a következő: A R E H K T. Jó okunk van tehát feltételezni, hogy a gyerekek kedvelik az újdonságokat, mivel a túlmodernizált mese eredetijét senki sem ismerte és a hiperkorrekciós eredeti történetet is csak a tanulók mintegy harmada, még- 
is elől szerepelnek azon a listán, ahol viszonylag sok megjegyzést füztek a mesékhez. Tehát ebből arra következtethetünk, hogy az újdonság ereje nagy, de nem a modern, hanem a klasszikus mesék esetén. Vagyis a befogadóra gyakorolt hatás tényleg nagyon szembetűnő, ahogy az az elővizsgálatból is kitűnt, még akkor is, ha ez a megjegyzésekből ilyen módon számszerűen nem volt kimutatható.

Összefoglalva tehát megállapíthatjuk, hogy a gyerekek első gondolata - a rövidített mesét és a túlmodernizált mesét kivéve - az volt, hogy a modern verzió tetszett jobban, ha azonban megjegyzést kellett hozzá írni, akkor az eredeti történethez írtak több megjegyzést a klasszikus történet kivételével, ahol egyértelműen a modern tetszett, illetve feltételezzük, hogy ennek modern átiratát tekintették kiindulópontnak.

Végül, de nem utolsósorban a gyerekek preferenciáiról néhány szó. Az elővizsgálat azt mutatta, hogy sokat tudnak a mesékről, de a mesékkel több csatornán keresztül találkoznak. Van olyan klasszikusnak számító Grimm-mese vagy magyar népmese, amelyet nem vagy csak kevesen ismernek, ezért jó okunk van feltételezni, hogy az interneten vagy a televízióban nem ezeket nézik. Míg a skálán mért tetszés azt mutatta, hogy nagyon 'menő' azt mondani, hogy ha valami modern, akkor mindig csak jobb lehet, addig a mesékről írt megjegyzések nem erről tanúskodnak. Szórakoztatónak tartanak egy modern, általuk eddig nem ismert történetet, mégis úgy tűnik a válaszaikból, az eredeti jobban megérinti őket. Ha pedig egy általuk ismert mesével találkoznak, annak modern változatából hiányolják azt, ami az eredeti történetet széppé, varázslatossá tette. Modellünk úgy tűnik, hogy működőképes, a jövőben pedig egy még nagyobb minta feltérképezése még árnyaltabb képet adhat a gyerekek preferenciáiról.

\section{Irodalom}

Éles Csaba (2007): Ember és esztétikum : Az esztétikai befogadás élményvilágai. Budapest: Cédrus Művészeti Alapítvány: Napkút Kiadó.

Gyöngyösiné Kiss Enikő (2007): A művészeti alkotások befogadásának személyiséglélektani perspektívája. In Czigler-Oláh (szerk.): Találkozás a pszichológiával. Budapest: Osiris, pp. 184-200.

Halász László (1972): Attitűd-dinamikai változások irodalmi mű befogadásában. In: Környezet és tevékenység. (Pszichológiai tanulmányok 13.) Budapest: Akadémiai Kiadó, pp. 437-442.

Halász László (1976): Műértékelés-kutatás és attitűdvizsgálat. In: Hunyadi-PatakiVáriné (szerk.): Szociálpszichológiai kutatások Magyarországon. Budapest: Akadémiai Kiadó, pp. 59-78.

Halász László: (2006). Művészetpszichológia. In: Bagdy-Klein (szerk.): Alkalmazott pszichológia. Budapest: Edge 2000 Kiadó, pp. 187-203.

Tóth István, H. (1994): A művet mindig ketten alkotják. In: Nagy Attila (szerk.): Olvasásra nevelés és pedagógusképzés. Budapest: Országos Széchényi Könyvtár, pp. 92-96.

Józsa Péter (1982): Az esztétikai alkotás hatásmechanizmusának társadalmi jellege. In: Hajdu-Ráfis-Kamarás (szerk.): Az olvasás anatómiája. Budapest: Gondolat, pp. 335-356. Kopházi-Molnár Erzsébet (2016): Mitől tetszenek a mesék. In: Nagyházi (szerk.): IX. Képzés és Gyakorlat Nemzetközi Neveléstudományi Konferencia: Nevelés és tudomány, neveléstudomány a 21. században. (tanulmánykötet) Kaposvár: Kaposvári Egyetem Pedagógiai Kar - Nyugat-magyarországi Egyetem Benedek Elek Pedagógiai Kar, pp. 210224. 
Kopházi-Molnár Erzsébet (2016): Olvassunk mesét... de melyiket? avagy rövid barangolás a modern meseátiratok útvesztőjében. In: Kolosai-Pintér, M. (szerk.): A gyermekkultúra jelen(tôség)e. Budapest: ELTE Tanító- és Óvóképző Kar, pp. 198-211.

László János (2002): Pszichológia, irodalom, elbeszélés. In: Czigler-Halász-Márton (szerk.): Az általánostól a különösig: Pszichológia. Budapest: Gondolat Kiadói Kör: MTA Pszichológiai Intézet, pp. 317-336.

Moffet, L. A. (1983): A műalkotások mint személyek: a művészetpszichológia új kutatási iránya. In L. Halász László (szerk.): Múvészetpszichológia. Budapest: Gondolat Kiadó, pp. 412-420.

Siklaki István (1980): Elbeszélő szövegekkel kapcsolatos kutatások. Budapest: Tömegkommunikációs Kutatóközpont.

Szalay, L. B. - Deese, J. (1978): Subjective meaning and culture : An assessment through word associations. Hillsdale, N. J.: Lawrence Erlbaum Associates

Tibori Tímea (2013): Az esztétikai befogadás vizsgálata. In: Kiss-Tibori: Kultúrkapuk: Tanulmányok a kultúr(politik)áról, az értékközvetítésről és a kulturális valóságról. Szeged: Belvedere Meridionale, pp. 179-227.

Tibori Tímea (1995): A művészet befogadásának tipológiája. In Vörös Gizella, B. (szerk.): Egy univerzális értelmiségi. Budapest: MTA Szociológiai Kutató Intézete, pp. 119-126.

Tibori Tímea (1986): Az esztétikai befogadás vizsgálata. Budapest: Művelődéskutató Intézet.

Tóth Beatrix (2013): Irodalmi nevelés az alsó tagozaton szépirodalmi epikus szövegek olvasásával és feldolgozásával. In: Podráczky Judit (szerk.): Múvészeti nevelés kora gyermekkorban : Módszertani kaleidoszkóp. Budapest: Bethlen Gábor Alapkezelő Zrt., pp. 1135.

Vigotszkij, L. (1968): Művészetpszichológia. Budapest: Kossuth Könyvkiadó.

\section{SUMMARY}

\section{Measurement of the reception of fairy rales - a possible model}

It is always a difficult task to make a survey among little children. If we want to have several kids interviewed, it is very time-consuming. If we want them to fill in a questionnaire about a tale told, it might not give us the information we really are looking for. It is especially true if we want to grasp the young ones' experience in connection with the tales they have listened to and not to interrogate them in connection with the information we think is important in the tales from the point of the view of the understanding of the story. The aim of the present study is to introduce a possible model with the help of which we can make a survey among children quite easily. We have used the free word association method to see how the children relate to different modern re-written fairy tale types and their original story. Before the main survey we have conducted a preliminary research when nearly four hundred - mainly second grade - children wrote down words and expressions related to their preference for tales. Having listed the items written by them, we have asked coders to put the expressions into categories, which served as a basis for further comparison. We have chosen six pairs of tales (a classical story and its modern pair) which have represented different types of re-written versions of fairy tales. After pre-stesting we have told the six pairs of tales in six different schools to thirty (fifteen boys and fifteen girls) schoolchildren. Besides the free word association method we have also used a colourful thermometer (that is a 0-5 scale), with the help of which they had to indicate how much they liked the tale. Every single sheet of paper has been coded and the results have been evaluated with the help of SPSS program. The results we could see on the 
thermometer - that is on the scale - was not always the same as what (and how much!) the chidren wrote about the tales. The analysis of the answers gained, the explanation of the results proved to be a really exciting task.

Keywords: types of modern re-written fairy tales, morphological examination, reception of tales, free word association 